\title{
Preventing Criminality in Albania
}

\author{
Jonida Skëndaj \\ Phd candidate, Department of Legal Sciences, "Albanian University", Tirana, Albania \\ Email: jonida.skendaj29@gmail.com
}

\section{Doi:10.5901/ajis.2015.v4n2s2p264}

\begin{abstract}
The purpose of this paper is to present a summary of the standards, norms, elaboration of specific policies for the prevention of crimes, various prevention strategies, the classification of prevention measures and the role of the Albanian criminal justice system in the prevention of crime and victimization. During the last decade in Albania have been positive changes in legislative aspect. Legal reforms have been multilateral. Are approved, amended and ratified many laws and are part of the albanian legislation conventions and international agreements however there is still more work to do before. As a conclusion, in preventing of criminality is important cooperation between state bodies, various organizations of civil society and foreign organizations operating in Albania who deal with the implementation of strategies for fighting against criminality. For these reasons strengthening of the criminal policy in two main directions: punitive politics and crime prevention constitutes the main current task.
\end{abstract}

Keywords: prevention of criminality, criminal justice, legal reforms, international conventions

\section{Introduction}

Prevention of criminality has been and remains a major concern for the Albanian society. Increased crime in society prompted researchers that, after the second half of the century. XX, to have in the center of their studies control of crime in society and the development of the criminal justice system for its prevention. Conception and ways of realizing the prevention of crime have changed, being perfect and enriched. For a long time, about the notion "crime prevention" was not achieved a unified definition. According to the dictionary of Criminology (Hughes, 2001), with crime prevention understood any action or tool used by state bodies or agencies that aims to minimize the damage that can cause criminal offenses. United Nations Organization drew up a guideline to prevent crime (UNCommission, 2002), according to which, crime prevention means a set strategies and measures that aim to reduce the risks and the harmful effects of crime and fear against him. This guide does not speak for the implementation of laws, penalties and penitentiary institutions (prisons), although even these have preventive functions. These rules are mentioned in another document of the United Nations, entitled "Summary of standards and norms of the United Nations for crime prevention and criminal justice" (United Nations Publication, 2006).

\section{Theoretical aspects}

Considering the developments in our country migration and emigration, mixtures of cultures and a series of problems with economic and social character, early prevention of crime takes great importance. Today there are different models and programs to prevent crime. These prevention programs of crime are known as general prevention measures (primary prevention), special prevention measures or specific (secondary prevention) and tertiary prevention measures. Primary prevention is addressed to all population and aims to prevent possibilities of crimes committed; Secondary prevention aims forestalling the commission of the offenses, influencing in the prevention of involvement of persons in crime; tertiary prevention aimed minimizing dangerousness of authors by treating them (Hughes, 2001).

In our days these types of preventative measures combined with each other. These accomplished through initiatives to many institutions outside the criminal justice system (Young, 2001). For these initiative planned and coordinated there is the thought that social and health services, private charity agencies and the police play an important role in crime prevention. (Hughes, 2001

The experience of Western countries offers numerous models of crime prevention. Among the countries with experience in the prevention of criminality are England and the US, which have been as a reference for many countries to 
design prevention programs. Almost all developed countries apply programs to prevent the situations that can lead to crime. Such programs aim to lessen the dangers that can come from several criminal offenses. This is achieved by intervening in their causes (Ekblom, 2001). Crime prevention programs, initiated by the Chicago schools aim to improve the social aspects of life disorganized communities, infrastructure and institutions in them.

\section{Methodology}

Criminal policy should be oriented towards reducing as much as possible of criminality. It is known that crime is accompanying of human society. At any time, criminal policy defines tools, which aim reducing crime and punishment of prevalent crimes in a country, but it can't completely eliminate them. European orientation is towards the use of social strategies, which improve the general situation in the country, reduce the impact of criminal factors and predict different penalty alternatives for the integration of convicted persons in society (Elezi \& Hysi, 2006).

Compilation of criminal policy can not be achieved if there are no studies and research in this area. Importance are studies, experience of the employees of practice including employees of different professions, such as psychologists, social workers etc, who contribute in the implementation of modern criminal policies. Studies of distinguished authors as (Elezi; Hysi Selih ; Haines ; Hugdes \& Ekblom) and some important documents such as international pacts, summary international acts, European conventions, recommendations of the Council Europe and progress reports (progress report) for the role of the criminal justice system to prevent crime are the main part of this paper. This study includes the mode of operation of the police, prosecution, criminal judicial system, prison system and the role of probation service in the prevention of criminality.

\section{The role of the albanian criminal justice system in the prevention of criminality}

\subsection{The role of the police in crime prevention}

The police is an important actor in the prevention of crime, but not the only. It has a dual position: has the duty to protect the rights of citizens from infringement of other persons actions, on the other hand the police may infringe their rights if they do not respect the standards for persons sentenced to imprisonment (Hysi, 2010).

By assessing the possibility of infringement of rights by the police as a body to which law gives the right to deprived freedom, international organizations as the UN, Council of Europe and the European Union, have developed a series of minimum rules that must be respected in cases where it is necessary to remove freedom persons according to ages, gender or social position assigned.

\subsection{Prosecution and its role in the prevention of crime}

The role of prosecution in crime prevention is expressed above all in the criminal policy that follows this body where a special importance have policies proceeding as (beginning the criminal case and suspension and sending in the trial of a criminal case). Policy processing depends on laws, but also by structures that work for implementing them. The prosecution has created specialized structures (EU, 2008 \& EU, 2009) in investigating and combating new forms of crime which are: Department of financial intelligence that deals with the prevention of money laundering ; Department of computer crime, June 2009; Agency for the management of seized assets, system (MEMEX) which enables the exchange of information for investigations in the field of drugs in central and local level, Office of the National Coordinator for the fight against human trafficking. Creating new structures, outside the prosecution system, as the Ministry of Finance is a feature that we see in all reforms undertaken recently in Albania for preventing and combating organized crime, financial crime and data collection for cleaning money. Creation of specialized agencies is a widespread phenomenon in several European countries and reflects the combination of the continental model with that anglo-saxon in the investigation of these crimes, bringing developments that need to be evaluated seriously (Selih, 2000).

\subsection{Judicial system and the prevention of crime}

Criminal justice system, can play an effective preventive role. Today, the way of functioning of the system is changed depending on the model chosen: model of crime control or model of crime prevention. This system in Albania has undergone a reform process, especially on the way of the organization of the courts, the number of judges and budgets 
for the judiciary, which are an important element in the strengthening of democracy, respect for human rights and the state of right. Criminal Justice begins to play its preventive role at the moment when people participating in the process go to the doors of the police, prosecution or court and seek to have access to their services, be informed about the processes, the time of their development, for the phase in which is located issue for which they are interested etc.

Access to justice is a problem for some layers in society, such as those in social and economic weak position, victims of trafficking, minors, some minority groups and people with different sexual orientation. It is for this reason that the Council of Europe has adopted several recommendations and resolutions regarding free legal aid (COE, 2005). The European Convention of Human Rights treats this aspect as an element of regular judicial process (ECHR, 1953).

\subsection{The criminal justice system and crime prevention}

This system has a duty not only to rehabilitate the convicted person but also to prevent the recidivism. It is for this reason that the UN, COE and EU have developed minimum standards for the treatment of persons sentenced to imprisonment (UN Commission, 2002). Many national and international documents sanction prohibition of torture and other inhuman and degrading treatments and define the rules for the treatment of various social groups, persons serving sentences for e.g sentence with life imprisonment. The prosecution and the judicial system can contribute to an effective preventive policy in the prison system through the implementation of alternative sentences and appropriate sentence policies for women, minors, the elderly.

\subsection{The role of Probation Service in the prevention of crime}

Probation is a state body that oversees the implementation of alternative sentences, provides information and reports to the prosecutor or the court, and helps the convicted persons to overcome the difficulties for social reintegration. Appreciating the role of this service (Haines, 2009), with interest is its use in the criminal justice system. Haines scholar, expresses the opinion that this service has no significant impact on reduction in crime (Haines, 2009). This mechanism aims to reduce overcrowding in prisons and to find appropriate ways to rehabilitate the person.

\section{Discussion}

Speaking of crime prevention, today more and more arises the question: criminal justice or restorative justice is more effective in preventing crime? From the studies that have been made in international practice turns out that there is no single definition of restorative justice. Nowadays it is considered as a process that aims to regulate the damage came from the offense and establishing peace between the parties in conflict (Elezi, 2008).

It is based on the concept of damage caused such as material, psychological or social, and focus more on repairing this damage, prompting thereby enhancing the role of the individual in resolving disputes. Currently in Albania, the concept of Restorative Justice is not unknown. As the most widespread form of its is mediation. Mediation procedures regulated by law, (no.10385, dated 02/24/2011) "For mediation to resolve disputes". The law provides that mediation is performed in cooperation with "probation service" which oversees the implementation of alternative sentence and helps the reintegration of the convicted person .

Restorative Justice is often posited as a cheaper, more effective alternative to imprisonment, but it has the shortcoming of relying almost solely on the permission and participation of the victims. This report seeks to discover and analyse possible barriers to victim engagement in Restorative Justice with a view to making recommendations on how to remove or alleviate these. By creation of a Literature Review, it was discovered that, although popular media represents a usually negative view of Restorative Justice, the majority of victims and offenders in studies discussed felt positively about it. The statistics also showed Restorative Justice in a good light when considering recidivism. Overall, there was a general view that Restorative Justice can be good for both victims and offenders in certain situations, but can also be damaging if not applied properly (Grief, 2007). In such conditions must overcome challenges and, when are the conditions, restorative justice be given the right place.

\section{Conclusions}

Regional and international cooperation is a European criminal policy orientation towards the prevention of criminality. This collaboration is dictated more and more today by organized economic, financial crime and increasing threat. 
Thanks to the ratification of the conventions and agreements in the field of criminal cooperation Albanian police and prosecutors have cooperated with counterpart institutions (http://www.pp.gov.al). Today it is necessary to develop a network of cooperation between the European Union institutions, countries and governments. The challenge for criminal justice is the prevention of victimization and victim rehabilitation. What is recommended is that in all cases should be respected the interest of the victim. In practice of our country is not applied properly protection of the victim and her family members. In cases of serious crimes, victims and families are seriously threatened. To avoid unpleasant consequences even dangerous for the victim the legislation of each country should predict measures for the protection of the victim. Today paid more attention, public opinion participation as well as victims in drafting of preventive criminal policies and their implementation.

\section{References}

Hughes, G. (2001). Crime prevention, "The sage Dictionary of Criminology", Sage, 63. http://www.crime-preventionintl.org/io_old/english/features/pdf/UNCommission0254281e.doc, 10.

United Nations publication. (2006). Compendium of United Nations Standards and Norms in Crime Prevention and Criminal Justice, United Nations, No. E.92.IV. 1.

Hughes, G. (2001). Crime prevention, "The sage Dictionary of Criminology", Sage, 62.

Young, J. (2001). Social crime prevention, "The sage Dictionary of Criminology", Sage, 272.

Hughes, G. (2001). Multy-agency crime prevention, "The sage Dictionary of Criminology", Sage, 177-178.

Ekblom, P. (2001). Situational crime prevention, "The sage Dictionary of Criminology", Sage, 263.

Elezi, I \& Hysi, V. (2006). Criminal Policy, Pegi, Tirana, 142.

Hysi, V. (2010). Criminology, Kristalina, Tirana, 2010, 408.

OKB. (1993). United Nations Convention "Against Torture and other inhuman or degrading treatments " international acts Summary, KSHH, Tirana, 1993.

Council of Europe. (2006). European Convention "On prevention of torture and inhuman or degrading treatment" European Treaty Series no.126, Tirana.

EU. (2008). Progress report for Albania, 46 - 50.

EU. (2009). Progress report for Albania, 47 - 53.

Selih, A. (2000). The prosecution process and the changing role of the prosecutor, Council of Europe, 106.

Council of Europe. (2005). Rec 93 (1) "For effective access to law and justice for every poor person ".

ECHR. (1953). Article 6, point. 3

UN Commission. (2002). Guide of the United Nations for Crime Prevention, http://www.crime-prevention-intl.org/io_old/english /features/pdf/ UNCommission0254281e.doc.

Haines, K. (2009). Manual for employees of Probation Service, OSBE, 2009, 23.

Haines, K. (2009). Manual for employees of Probation Service, OSBE, 2009, 22.

Elezi, I. (2008). Prevention, criminal justice and restorative justice, the intermediate magazine, no 128, Tirana, 2008, 39-50.

Grief, E. (2007). Restorative Justice: How it Works, Jessica Kingsley, London, 33. http://www.pp.gov.al/sq/home/koperime.html

Law. (2011). "For mediation to resolve disputes" no.10385, Tirana. 